\title{
Too small to fail
}

\author{
Chad Klochko, M.S.
}

Michigan State University, College of Human Medicine

0 n December 7, 2012, Nicholas Kristof, ${ }^{1}$ two-time Pulitzer Prize winning journalist, wrote a compelling article about people in poverty in the United States. The article, which appeared in the New York Times, describes the plight of young children who are failing in school and who are not acquiring the skills needed to move forward in their education, and tragically, in some cases, parents are allowing them to fail. It is their children's illiteracy that enables the parents to receive Supplemental Security Income (SSI) payments from the government. These payments, meant for supporting families of children with severe functional limitations, are funds that the family uses to survive. The parents were most likely members of an educational system that failed them as well, leaving them without the academicbased life skills needed to get better paying jobs. And so a vicious cycle results with far-reaching consequences, including an abysmal education, unemployment, poorer health, and inadequate healthcare. Solutions to breaking this cycle seem impossible, but we cannot accept failure and give up. Solutions will begin with small steps, which is how every journey begins. And confidence must be drawn from what Mark Twain once said: 'They didn't know it was impossible, so they did it.'

Ruffing and Pavetti ${ }^{2}$ criticize Kristof's article, stating that his information on SSI 'should be rooted in facts and data, not impressions, misimpressions, and anecdotes,' and go on to iterate, 'This is not to say no such incidents occur, or that all families take full advantage of supplemental literacy or tutoring programs that may be available (though not always accessible) to them.' But they would prefer commentary based on 'actual research' versus 'anecdotal stories.' Kristof, never averse to raising the specter of social problems of the minority, leaves the conducting and analyzing of research to the academics and think tanks. However, he does, in fact, cite research he believes supports his claims. A 2011 report from the Committee on Ways and Means found that four decades ago, approximately $1 \%$ of poor children had support from the SSI payment system. ${ }^{3}$ A 2012 report from the Social Security Administration cited that $8 \%$ of children in poverty today are enrolled in $\mathrm{SSI}^{4}$ This increase in SSI support correlates with less stringent eligibility requirements for families in the program and ends up with the majority of beneficiaries transitioning into SSI in adulthood and the others being largely unprepared for life without SSI. ${ }^{5}$ Of significance is a finding by DeCesaro and Hemmeter. 'The choice to return to work might be especially difficult for many child SSI recipients who have unmet health needs and fear losing future access to health benefits through Medicaid'.

Save the Children is taking steps to improve literacy by striving to find answers for children whose poverty has affected their education. Save the Children is a non-profit organization dedicated to helping children both in the United States and around the world. ${ }^{7}$ They respond to emergency situations, where medical aid, shelter, and other relief are needed, and they also administer strategic programs to improve the education of children. They posit that 'Education is the road that children follow to reach their full potential in life'. ${ }^{8}$ They have initiated education projects training teachers in the use of more effective teaching strategies, offering ways for volunteers to get children to read and do math outside of school hours, and promoting the power of artistic expression to help children heal, learn, and do better in school. In the United States, they are working in poverty-stricken areas, teaching parenting skills and providing parents with their greatest need - hope. Kristof is getting the message out, believing that helping struggling children should be a national priority. He contends, 'They're too small to fail.'

The implications of illiteracy factor into all facets of a person's life, including their healthcare. People require health literacy, which is defined as the degree to which individuals have the capacity to obtain, process, and understand basic health information and services needed to make appropriate health decisions. ${ }^{9}$ Individuals with literacy problems are unable to take full advantage of healthcare services. Weir ${ }^{10}$ cogently delineates the literacy spectrum and offers a reflection:

There are several types of literacy. Prose literacy is the ability to understand and use information from texts such as news stories and fiction, whereas document literacy is the ability to locate and use information from documents such as job applications and transportation schedules. Numerical literacy is the ability to balance a checkbook or complete an order form. To package these varied skills into the binary outcome of "pass or fail," as the provincial test has done, too starkly paints the shades of literacy in black 
and white, and knocks the self-esteem of many Ontario teenagers in the process.

Self-esteem is intrinsically tied to illiteracy. A recent qualitative study of the perspectives of adults with low literacy skills revealed how much patients feared that their poor reading skills would be exposed. "I don't tell anybody or say anything [about my illiteracy]," said one. "They might think I'm a bad person." However, the consequence of nondisclosure in a health care setting is uninformed consent. "A lot of times I thought, 'My God, I am signing my life away,' said another study participant.

The effectiveness of the healthcare we offer is influenced by the literacy of our patients. If patients cannot read directions on their medications, they are in jeopardy. If caregivers do not follow medical protocols because they have limited literacy capabilities, dangerous consequences can result. If people cannot do the math needed to properly dispense medications, they can over-or-under dose. In 2003, the National Assessment of Adult Literacy (NAAL) introduced a health literacy component to their national assessment of adults' ability to use their literacy skills; the health component measures understanding health-related materials and forms. ${ }^{11}$ Findings indicate poverty and limited education negatively affect health literacy.

Literacy begins by teaching all children how to read and compute so that one day they can get good jobs, effectively handle their healthcare, and lead healthy, fulfilling lives. In our country, people worry about the banks that might be too big to fail. What about the children who do not have a voice in voting or a platform so their needs can be heard? By assuring literacy for every child, we would be taking a great stride to embolden those who are too small to fail.

\section{REFERENCES}

1. Kristof N. Profiting from a child's illiteracy. The New York Times, 7 December 2012. Available from: http://www.nytimes. com/2012/12/09/opinion/sunday/kristof-profiting-from-achilds-illiteracy.html?pagewanted $=$ all\&_r $=0$ [cited 23 January 2013].

2. Kathy R, Pavetti L. SSI and children with disabilities: just the facts. Center on Budget and Policy Priorities. Available from: http://www.cbpp.org/cms/index.cfm?fa=view\&id=3875 [cited 23 January 2013].

3. U.S. House. Committee on ways and means. Supplemental security income for children hearing, 17, October 2011. Available from: http://waysandmeans.house.gov/news/ documentsingle.aspx?DocumentID=270423 [cited 19 January 2013].

4. Social security administration. Annual statistical supplement report, 2012 (Table 7.e4). Available from: http://www.ssa.gov/ policy/docs/statcomps/ssi_asr/2010/sect10.html\#table69 [cited 17 January 2013].

5. Hemmeter J, Kauff J, Wittenburg D. 2009. Changing circumstances: experiences of child SSI recipients before and after their age-18 redetermination for adult benefits. J Vocat Rehabil 30:201-21. http://dx.doi.org/10.3233/JVR-2009-0462. 6. DeCesaro A, Hemmeter J. 2009. Unmet health care needs and medical out-of-pocket expenses of SSI children. J Vocat Rehabil 30:3. http://dx.doi.org/10.3233/JVR-2009-0461.

7. About Us. Save the Children. (2012, December). Available from: http://www.savethechildren.org/site/c.8rKLIXMGIpl4E/b. 6146405/k.C7E9/About_Us.htm

8. The Power and Promise of Education. Save the Children. (n.d.). Available from: http://www.savethechildren.org/site/c. 8rKLIXMGIpI4E/b.6153015/k.E633/Education.htm [cited 23 January 2013].

9. What is Health Literacy? National Institutes of Health. (2012, March 5). Available from: http://www.nih.gov/ clearcommunication/healthliteracy.htm

10. Weir E. 2001. Illiteracy as a public health issue. CMAJ 164:1486. Available from: http://www.cmaj.ca/content/164/10/ 1486.full.pdf + html [cited 23 January 2013].

11. Kutner $M$, Greenberg $E$, Jin $Y$, Paulsen $C$. The health literacy of America's adults: results from the 2003 National Assessment of Adult Literacy. National Center for Education Statistics. Available from: http://nces.ed.gov/pubs2006/2006483.pdf [cited 23 January 2013]. 